ratios calculated from analyser rotations. The ratio of reflectivities calculated from values of the optical constants (Lenham, A. P., private communication) for the same crystal, is included for comparison.

Measurement of the analyser rotation angle thus provides a rapid method of determining the tilt of the optic axis ( [0001] on hexagonal indexing, [111] on both rhombohedral descriptions). The accuracy is probably limited to about $\pm 5^{\circ}$ with standard equipment, but the method can be used with polycrystalline samples even if the grain size is small.

$$
\text { H. D. Mallon }
$$

I. G. RUNCIMAN

Metallurgy Branch,

Royal Military College of Science, Shrivenham.

' Hare, G. A., and Mallon, H. D., Metallurgia (in the press).

${ }^{2}$ Mallen, H. D., and Wilson, C. G., Brit. J. App. Phys. (in the press).

\section{Effect of Moisture on Carboxylic Acid Adsorption to Steel}

QUALITATIVE evidence has been given ${ }^{1}$ that oils compounded with efficient dicarboxylic (alkylated succinic acids) rust inhibitors will not prevent rusting at certain low concentrations of the additive. When oil at these low concentrations of inhibitor was saturated with water, however, rust protection was obtained. Von Fuchs attributed this behaviour to the chemical reaction of iron with water to form ferrous hydroxide, which in turn can react with the acidic inhibitor to form a tenacious film of soap on the metal surface. Another investigation ${ }^{2}$, using stearie acid labelled with carbon-14, demonstrated that the acid is adsorbed more readily to ferrous surfaces from hydrocarbon solution containing entrained moisture than from a relatively dry solution. This phenomenon of enhanced adsorption to the metal surface was explained by Ries et al. as probably being due to an increase in the oxide coating produced by the presence of moisture.

In this work it was discovered that the adsorption could be enhanced not only by moisture in the oil, but also by an invisible layer of moisture adsorbed on the metal surface prior to application of the oil. This suggested a means of determining the mechanism of the water catalysis, since if the phenomenon is due to an increase in oxide surface, the effect would be observed on a surface originally treated with moisture even if it were dried thoroughly before applying the inhibited oil.

To determine the relative amounts of carboxylic acid adsorbed from an oil solution on to the back surface of a polished steel planchet, an alkylated succinic acid labelled with carbon-14 was used. Three drops of a 0.015 per cent solution of the acid in mineral oil were deposited on a planchet surface. After $2 \mathrm{~min}$. of contact at room temperature, the oil was blotted off thoroughly with filter paper and the radioactivity remaining on the planchet determined. This residual activity is equal to the activity adsorbed to the surface plus the activity remaining in the thin film of oil not removable by blotting. Any increase in this total residual activity resulting from variations in preparation of the metal surface must be due, of cousse, to increased adsorption of the radioactive species to the surface. Treatment of the polished planchets before depositing the radioactive oil consisted of exposure to a column of steam for varying periods of time ranging from 30 sec. to $4 \mathrm{~min}$. After this exposure, Table 1. EFFect of MoIsture on Adsorption of an ALKYlate?
SUCCINIC ACID ON TO SMOOTh STEEL SURFACES

\begin{tabular}{|c|c|c|c|c|}
\hline $\begin{array}{l}\text { Sample } \\
\text { No. }\end{array}$ & $\begin{array}{c}\text { Ex- } \\
\text { posure } \\
\text { to } \\
\text { steam } \\
\text { (sec.) }\end{array}$ & $\begin{array}{l}\text { Resulting condi- } \\
\text { tion of surface }\end{array}$ & $\begin{array}{l}\text { Heat drying } \\
\text { treatment after } \\
\text { steam exposure }\end{array}$ & $\begin{array}{l}\text { Residual } \\
\text { activity } \\
\text { after } \\
\text { blotting } \\
\text { off oil } \\
\text { (counts } \\
\text { min.) }\end{array}$ \\
\hline 1 & 0 & & & 438 \\
\hline 2 & 0 & & & 464 \\
\hline $\begin{array}{l}3 \\
4\end{array}$ & $\begin{array}{l}30 \\
30\end{array}$ & no visible rust & none & 824 \\
\hline 5 & $\begin{array}{l}50 \\
30\end{array}$ & $\begin{array}{l}\text { no visible rust } \\
\text { no visible rust }\end{array}$ & $120^{\circ}$ C. for 3 days & 372 \\
\hline 6 & 60 & incipient rusting & $\begin{array}{l}120^{\circ} \text { C. for } 3 \text { days } \\
\text { none }\end{array}$ & 398 \\
\hline 7 & 60 & incipient rusting & $\begin{array}{l}\text { none } \\
\text { none }\end{array}$ & $\begin{array}{l}1,150 \\
1,451\end{array}$ \\
\hline 8 & 60 & incipient rusting & $120^{\circ} \mathrm{C}$. for 3 days & 534 \\
\hline 9 & 60 & incipient rusting & $120^{\circ} \mathrm{C}$. for 3 days & 464 \\
\hline 10 & 240 & heavy rusting & none & 1,833 \\
\hline 11 & 240 & heavy rusting & $120^{\circ}$ C. for 3 days & 568 \\
\hline
\end{tabular}

the visible layer of condensed steam was allowed to evaporate, leaving behind the invisible film of adsorbed moisture. Half the metal samples thus obtained were immediately treated with inhibited oil. The other half were dried in an oven at $120^{\circ} \mathrm{C}$. for 3 days to remove the invisible adsorbed film of moisture, before application of the oil. The results of the experiments are given in Table 1.

It can be seen that even if the surface oxide area of a steel specimen is enormously increased through exposure to moisture, there is little increase in absorption if the surface is dried thoroughly before applying the oil. On the other hand, surfaces exposed to moisture under conditions resulting in very little increase in the surface oxide area will undergo a tremendous increase in adsorptive capacity for carboxylic acids if the adsorbed layer of water molecules is not removed before treatment with the acid. The effect of water in increasing the adsorption of carboxylic acids from oil solution on to iron surfaces is consequently not due primarily to an increase in the surface oxide area of the metal, but rather to direct participation of the water at the time of the adsorption reaction.

The opinions or assertions contained in this communication are our own and are not to be construed as official or reflecting the views of the Naval Service at large.

Material Laboratory,

New York Naval Shipyard, Brooklyn 1, Now York.

M. E. SChrader

J. L. Kalinsky

on Fuchs, G. H., "Evaluation and Performance of Turbine Oils" A.S.T.M. Spec. Tech. Pub. No. 211, 93 (1956).

2 Ries, jun., H. E., Cook, H. D., and Loane, C. M., "Evaluation and Performance of Turbine Oils", A.S.T.M. Spec. Teeh. Pub. No.
211, 55 (1956).

\section{RADIATION CHEMISTRY}

\section{Chemical Effects of lonizing Radiation on Deoxyribonucleic Acid in Dilute Aqueous Solution}

WHEN purine and pyrimidine nucleotides in dilute aqueous solution are irradiated with ionizing radiation they are destroyed by two pathways'. The minor pathway is attack upon the sugar moiety followed by release of free base ${ }^{1}$. Details of the mode of sugar attack have not been established; but possible reactions have been suggested by Daniels et al. ${ }^{2}$. The 